\title{
BADANIA PORÓWNAWCZE WPEYWU PARAMETRÓW TECHNOLOGICZNYCH FREZOWANIA WYBRANYCH STOPÓW TYTANU NA MOMENT SKRAWANIA I CHROPOWATOŚĆ OBROBIONEJ POWIERZCHNI
}

\begin{abstract}
Stopy tytanu znajdują zastosowanie w wielu gałęziach przemysłu. Z uwagi na wymogi związane z dokładnością wymiarowo-kształtową i jakością powierzchni często są poddawane obróbce skrawaniem. Jednak ze względu na ich właściwości należą do grupy materiałów trudnoskrawalnych. W pracy przedstawiono wyniki badań wpływu prędkości skrawania $v_{c}$ oraz posuwu na ostrze $f_{z}$ na moment skrawania i jego amplitudę oraz chropowatość powierzchni podczas frezowania próbek wykonanych ze stopów tytanu Ti6Al4V, WT3-1, WT22 oraz OT4-1. Badania przeprowadzono na 3-osiowym centrum obróbkowym. Do pomiaru momentu skrawania użyto siłomierza obrotowego Kistler 9125A. Istnieje zakres prędkości skrawania $v_{c}$, dla którego chropowatość powierzchni jest najmniejsza. Wykazano, że wartości momentu skrawania oraz amplitudy są silnie skorelowane $\mathrm{z}$ właściwościami materiału.
\end{abstract}

Słowa kluczowe: stopy tytanu, moment skrawania, amplituda momentu, chropowatość powierzchni

\section{Wprowadzenie}

Stopy tytanu, ze względu na takie właściwości, jak duża wytrzymałość właściwa (stosunek wytrzymałości do gęstości), możliwość użytkowania w wysokiej temperaturze i środowisku korozyjnym, dobra kompatybilność z tkanką ludzką, znajdują szerokie zastosowanie. Ze stopów tych są wytwarzane elementy samolotów, śmigłowców, okrętów, maszyn przemysłu chemicznego i spożywczego, a także implanty.

Przedmioty produkowane ze stopów tytanu charakteryzują się na ogół dużymi wymaganiami odnośnie do dokładności oraz chropowatości powierzchni, a w związku z tym są kształtowane metodami obróbki skrawaniem. Obróbka ta

\footnotetext{
${ }^{1}$ Autor do korespondencji/corresponding author: Kazimierz Zaleski, Politechnika Lubelska, ul. Nadbystrzycka 36, 20-618 Lublin, tel.: 815384238, e-mail: k.zaleski@ pollub.pl

2 Jakub Matuszak, Politechnika Lubelska, e-mail: j.matuszak@pollub.pl
} 
jest dość trudna ze względu na właściwości stopów tytanu, takie jak mały współczynnik przewodzenia ciepła, skłonność do tworzenia się narostu, duży współczynnik tarcia, mała wartość modułu Younga. Głównym problemem w obróbce tych stopów jest intensywne zużywanie się ostrzy narzędzi skrawających, ale też występowanie dużych sił i momentów skrawania. Pojawiający się narost i skłonność do występowania drgań mogą utrudniać uzyskanie wymaganej jakości powierzchni. Składowe całkowitej siły skrawania oraz chropowatość obrobionej powierzchni są ważnymi wskaźnikami skrawalności materiału [6-8].

$\mathrm{Z}$ analizy literatury wynika, że większość badań skrawalności stopów tytanu dotyczyła obróbki toczeniem. Wpływ głębokości skrawania podczas toczenia stopu Ti6A14V ELI (Grade 23) na chropowatość powierzchni i składowe całkowitej siły skrawania badano w pracy [12]. Autorzy pracy [13] analizowali siłę skrawania, posuwową i odporową w procesie obróbki stopu Ti6Al4V w funkcji głębokości i czasu skrawania. W artykule [15] przedstawiono równania regresji obrazujące wpływ głębokości skrawania, posuwu i prędkości skrawania na parametr $R z$ chropowatości powierzchni oraz siłę skrawania i posuwową w obróbce toczeniem stopu tytanu WT3-1. Chropowatość powierzchni stopu Ti6Al4V po toczeniu w znacznym stopniu zależy od posuwu oraz chłodzenia cieczą obróbkową [4], natomiast nie zauważono, aby na chropowatość powierzchni wpływało ciśnienie tej cieczy [11]. Jak wykazały badania przeprowadzone na stopie tytanu Ti-6Al-2Sn-4Zr-6Mo, na chropowatość powierzchni po toczeniu wykończeniowym wpływa zużycie ostrzy narzędzi [5]. Wyniki badań wpływu parametrów skrawania na chropowatość powierzchni stopu Ti6Al4V po toczeniu narzędziami o ostrzach $\mathrm{z}$ regularnego azotku boru oraz niepowlekanego i powlekanego węglika spiekanego przedstawiono w pracy [14].

Jednym z najczęściej stosowanych sposobów obróbki w procesie wytwarzania elementów ze stopów tytanu jest frezowanie. Autorzy pracy [2] badali chropowatość powierzchni stopu tytanu TA15 po frezowaniu z dużą prędkością skrawania $(250 \mathrm{~m} / \mathrm{min}$ oraz $350 \mathrm{~m} / \mathrm{min})$ narzędziami o ostrzach z polikrystalicznego diamentu (PCD) oraz polikrystalicznego regularnego azotku boru (PCBN). Stwierdzono, że narzędzia o ostrzach z PCD umożliwiają uzyskanie mniejszej chropowatości powierzchni w porównaniu z narzędziami z PCBN. Korzystny wpływ zastosowania frezów o zmiennej podziałce na drgania narzędzia podczas obróbki „,na sucho” cienkościennych elementów lotniczych ze stopu Ti6Al4V zauważyli autorzy pracy [3]. Wyniki badań wpływu parametrów trochoidalnego frezowania cienkich ścianek ze stopu Ti6Al4V na siłę skrawania, chropowatość powierzchni oraz błędy grubości ścianki zaprezentowano w pracy [10].

Oprócz badań eksperymentalnych, składowe całkowitej siły skrawania w obróbce frezowaniem stopu tytanu Ti6Al4V analizowano też metodą elementów skończonych. Badania symulacyjne wykazały, że istotny wpływ na składowe siły skrawania mają parametry skrawania, a w największym stopniu wpływa na nie wartość posuwu [1]. Z kolei w pracy [9] stwierdzono, że istotny wpływ na wyniki 
symulacji MES ma model konstytutywny materiału obrabianego, przy czym parametry modeli wyznaczono, opierając się na danych eksperymentalnych.

$\mathrm{Na}$ podstawie analizy literatury można stwierdzić, że w dotychczasowych badaniach skrawalności stopów tytanu był uwzględniany głównie stop Ti6Al4V, a otrzymane wyniki nie były porównywane $\mathrm{z}$ wynikami dla innych stopów tytanu. Do wytwarzania elementów maszyn mogą być stosowane różne stopy tytanu, dlatego uznano za celowe przeprowadzenie badań porównawczych momentu skrawania, siły biernej i chropowatości obrobionej powierzchni w procesie frezowania stopów Ti6A14V, WT3-1, WT22 oraz OT4-1.

\section{Metodyka badań eksperymentalnych}

Eksperyment przeprowadzono na centrum frezarskim AVIA800HS. Do badań użyto próbek wykonanych z czterech stopów tytanu: Ti6Al4V, WT3-1, WT22 oraz OT4, o wymiarach $100 \times 15$ x $10 \mathrm{~mm}$. W tabeli 1 przedstawiono skład chemiczny i właściwości fizyczne zastosowanych materiałów.

Tabela 1. Skład chemiczny i właściwości fizyczne stopów tytanu

Table 1. Chemical composition and physical properties of titanium alloys

\begin{tabular}{|c|c|c|c|c|c|c|c|c|c|c|}
\hline \multirow{2}{*}{ Symbol } & \multicolumn{8}{|c|}{ Skład chemiczny [\%] } & \multicolumn{2}{|c|}{$\begin{array}{l}\text { Właściwości } \\
\text { fizyczne }\end{array}$} \\
\hline & $\mathrm{Al}$ & V & $\mathrm{C}$ & $\mathrm{Fe}$ & Mo & $\mathrm{Cr}$ & $\mathrm{Mn}$ & $\mathrm{Ti}$ & $\begin{array}{c}R_{m} \\
{[\mathrm{MPa}]}\end{array}$ & HRC \\
\hline Ti6Al4V & $\begin{array}{l}6,25- \\
6,31\end{array}$ & $\begin{array}{l}4,09- \\
4,12\end{array}$ & $\begin{array}{c}0,026- \\
0,027\end{array}$ & $\begin{array}{c}0,18- \\
0,21\end{array}$ & - & - & - & \multirow{4}{*}{$\begin{array}{l}\stackrel{\Xi}{N} \\
0 \\
0\end{array}$} & 1014 & 33 \\
\hline WT22 & $5,6-5,7$ & 4,7 & 0,1 & 1,0 & $4,7-4,9$ & |0,8-0,9 & - & & 1173 & 35 \\
\hline WT3-1 & $5,5-5,6$ & - & 0,1 & 0,2 & $2,0-3,0$ & $0,8-2,3$ & - & & 910 & 32 \\
\hline OT4-1 & $1,5-2,5$ & & 0,1 & 0,3 & - & - & $0,7-2,0$ & & 630 & 25 \\
\hline
\end{tabular}

Próbki poddano procesowi frezowania czołowego przy użyciu frezu trzpieniowego firmy ISCAR o średnicy $D=20 \mathrm{~mm}$, z dwoma płytkami z węglików spiekanych o symbolu HM90 APKW 1003PDR. Zastosowano stałą głębokość frezowania $a_{p}$ oraz zmienne prędkości skrawania $v_{c}$ i posuwy na ostrze $f_{z}$. W tabeli 2 przedstawiono zestawy parametrów technologicznych skrawania. W celu wyeliminowania wpływu zużycia ostrza na efekty obróbki, dla każdego stopu zastosowano nowe płytki skrawające. W trakcie frezowania rejestrowano moment skrawania za pomocą siłomierza obrotowego Kistler 9125A. Ze stabilnego przebiegu siły (pomijając strefę wejścia i wyjścia) wyznaczono wartości średnie oraz amplitudy momentu skrawania. Na rysunku 1 przedstawiono widok stanowiska badawczego. Po procesie frezowania dokonano pomiarów chropowatości za pomocą urządzenia Hommel tester T1000. 
Tabela 2. Parametry technologiczne skrawania

Table 2. Cutting parameters

\begin{tabular}{|c|c|c|c|c|c|c|c|}
\hline$v_{c}[\mathrm{~m} / \mathrm{min}]$ & 40 & \multicolumn{4}{|c|}{60} & 80 & 100 \\
\hline$f_{z}[\mathrm{~mm} /$ ostrze $]$ & 0,1 & 0,05 & 0,1 & 0,2 & 0,3 & & 1 \\
\hline$a_{p}[\mathrm{~mm}]$ & & & & 0,5 & & & \\
\hline$a_{e}[\mathrm{~mm}]$ & & & & 15 & & & \\
\hline
\end{tabular}

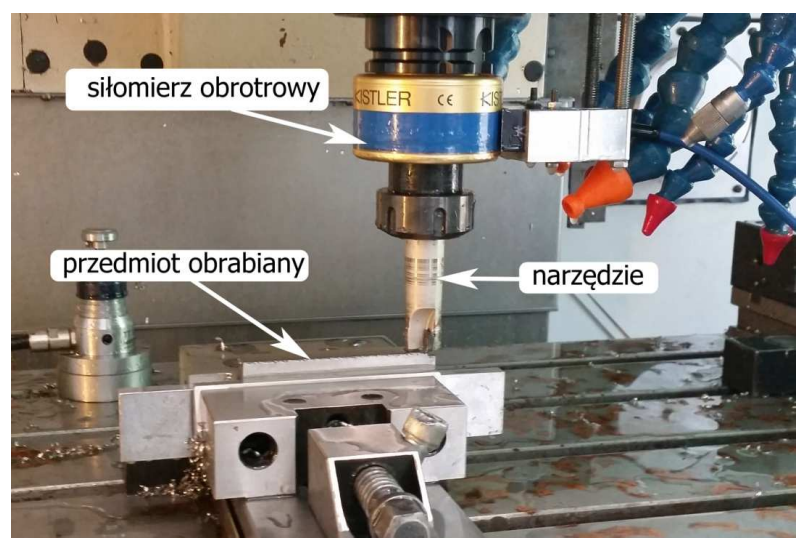

Rys. 1. Widok stanowiska badawczego

Fig. 1. The view of the test stand

\section{Wyniki badań}

Na rysunku 2 przedstawiono wykres wpływu prędkości skrawania $v_{c}$ na wartość parametru chropowatości $R a$. Dla stopów OT4-1, Ti6Al4V oraz WT3-1 - do prędkości $v_{c}=80 \mathrm{~m} / \mathrm{min}$ - wraz ze wzrostem prędkości obserwuje się nieznaczny spadek chropowatości powierzchni. Przy prędkości $v_{c}=100 \mathrm{~m} / \mathrm{min}$ widoczna jest zmiana trendu i wzrost wartości chropowatości. Można się spodziewać, że dalszy wzrost prędkości spowoduje wzrost chropowatości powierzchni. Z kolei dla stopu WT22 zaobserwowano wzrost chropowatości wraz ze wzrostem prędkości skrawania, przy czym wartości parametru $R a$ są wyższe w porównaniu z pozostałymi stopami, szczególnie w zakresie podwyższonych prędkości. Na rysunku 3 przedstawiono wykres wpływu posuwu na ostrze $f_{z}$ na chropowatość powierzchni. Wraz ze wzrostem posuwu chropowatość rośnie.

$\mathrm{Na}$ rysunku 4 przedstawiono wykres wpływu prędkości skrawania na moment skrawania dla badanych materiałów. Nie zaobserwowano znaczącego wpływu prędkości skrawania na moment skrawania. Dla stopów OT4-1, Ti6Al4V oraz WT3-1 moment skrawania zmieniał się w zakresie 0,8-1,0 Nm, natomiast widoczne są większe wartości momentu skrawania podczas frezowania stopu WT22, który zmieniał się w zakresie 1,3-1,5 Nm. Rysunek 5 przedstawia wpływ 


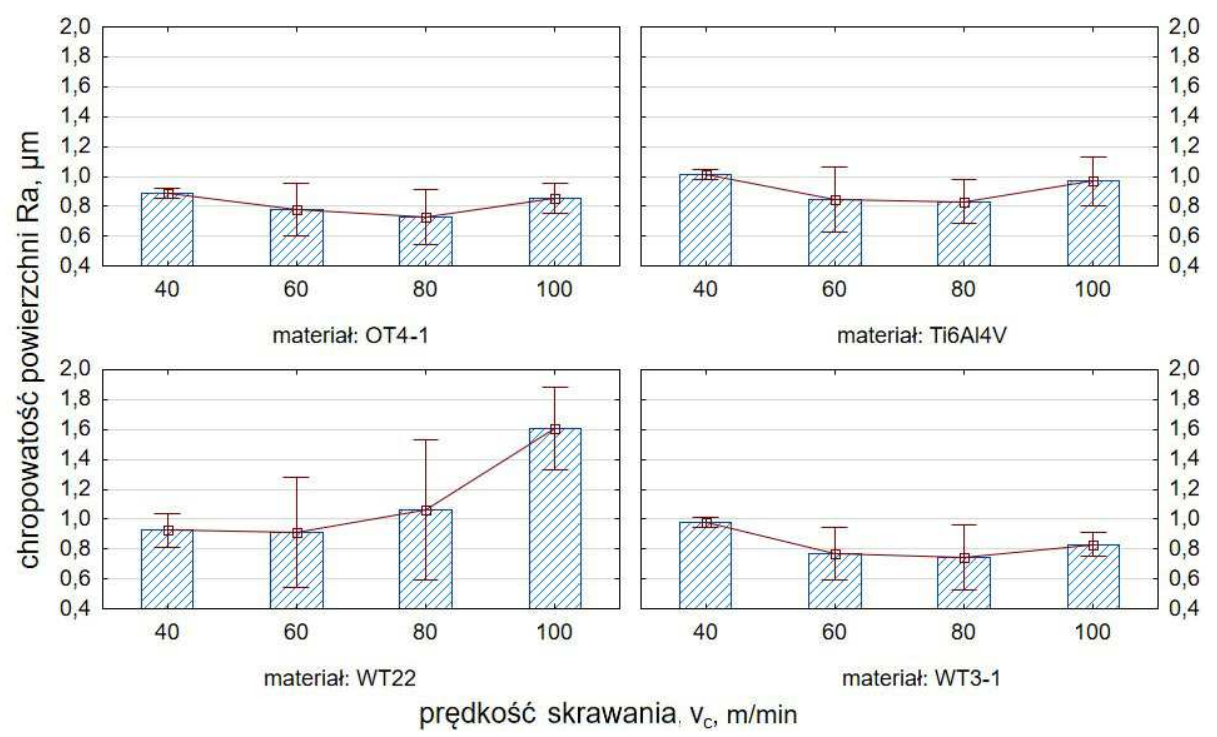

Rys. 2. Wpływ prędkości skrawania $v_{c}$ na chropowatość powierzchni (stały posuw $f_{z}=0,1$ $\mathrm{mm}$ /ostrze)

Fig. 2. The effect of cutting speed $v_{c}$ on surface roughness (constant feed per tooth $f_{z}=0.1$ $\mathrm{mm} /$ tooth)
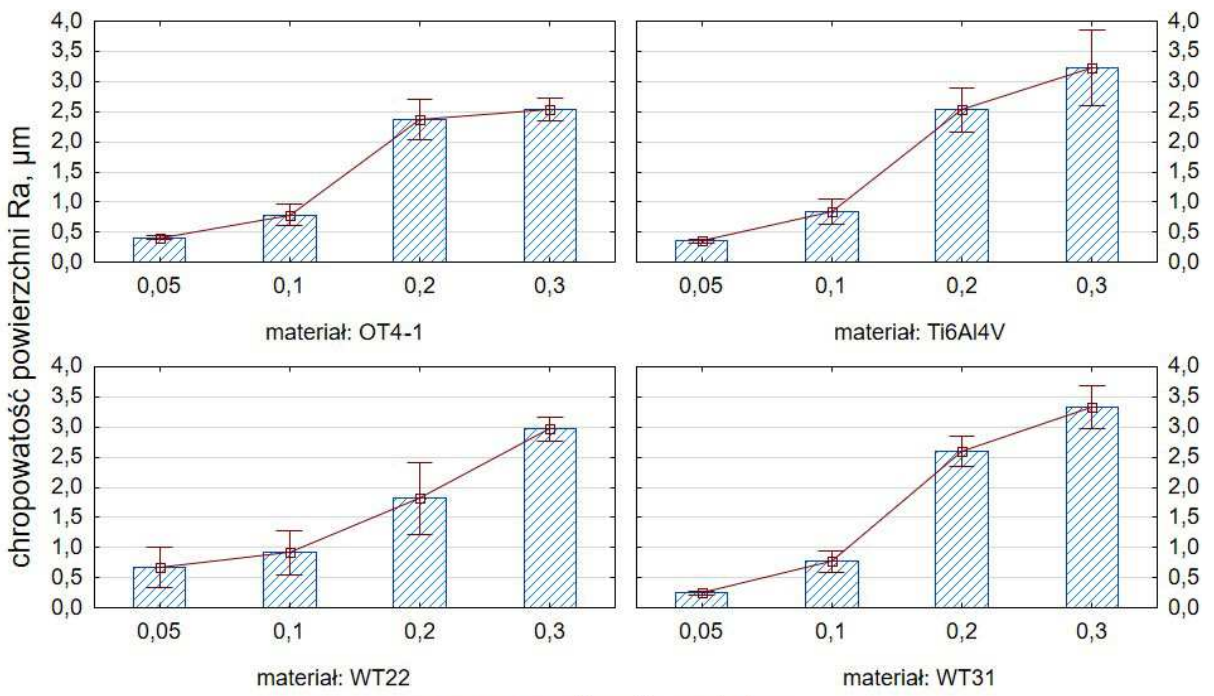

posuw na ostrze $\mathrm{f}_{\mathrm{z}}, \mathrm{mm} / \mathrm{ostrze}$

Rys. 3. Wpływ posuwu na ostrze $f_{z}$ na chropowatość powierzchni (stała prędkość $v_{c}=60 \mathrm{~m} / \mathrm{min}$ ) Fig. 3. The effect of feed per tooth $f_{z}$ on surface roughness (constant cutting speed $v_{c}=60 \mathrm{~m} / \mathrm{min}$ ) 


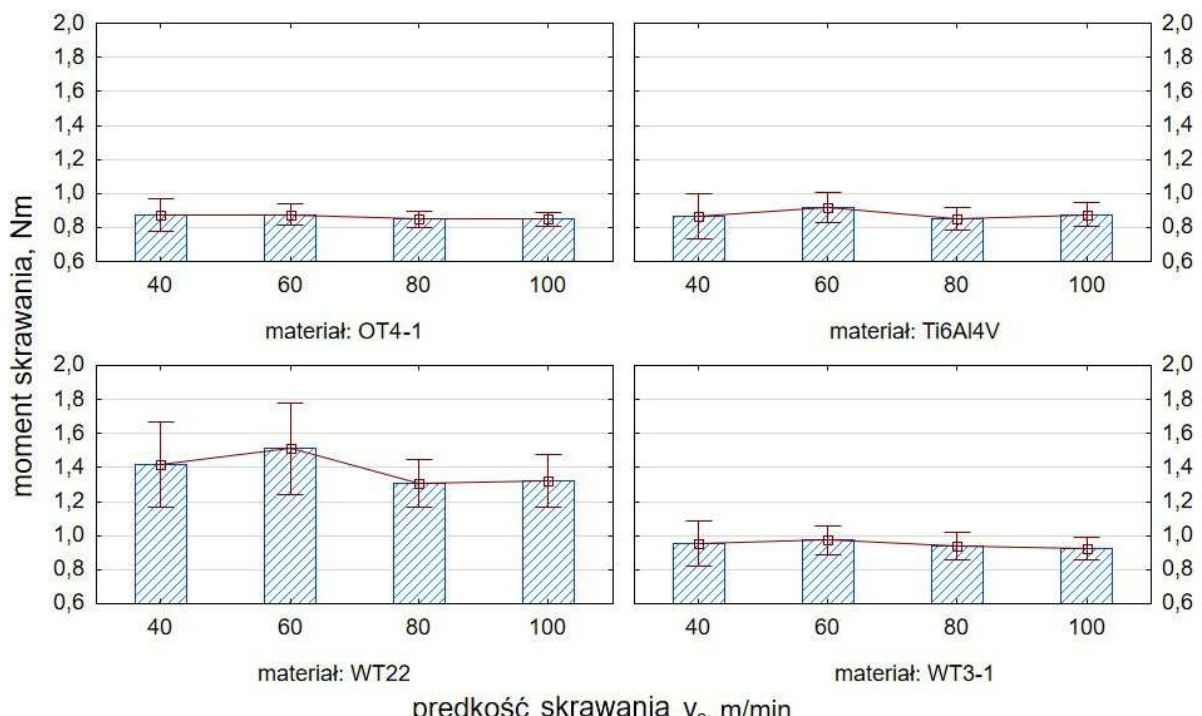

Rys. 4. Wpływ prędkości skrawania $v_{c}$ na moment skrawania (stały posuw $f_{z}=0,1 \mathrm{~mm} / \mathrm{ostrze}$ )

Fig. 4. The effect of cutting speed $v_{c}$ on cutting torque (constant feed per tooth $f_{z}=0.1 \mathrm{~mm} /$ tooth)

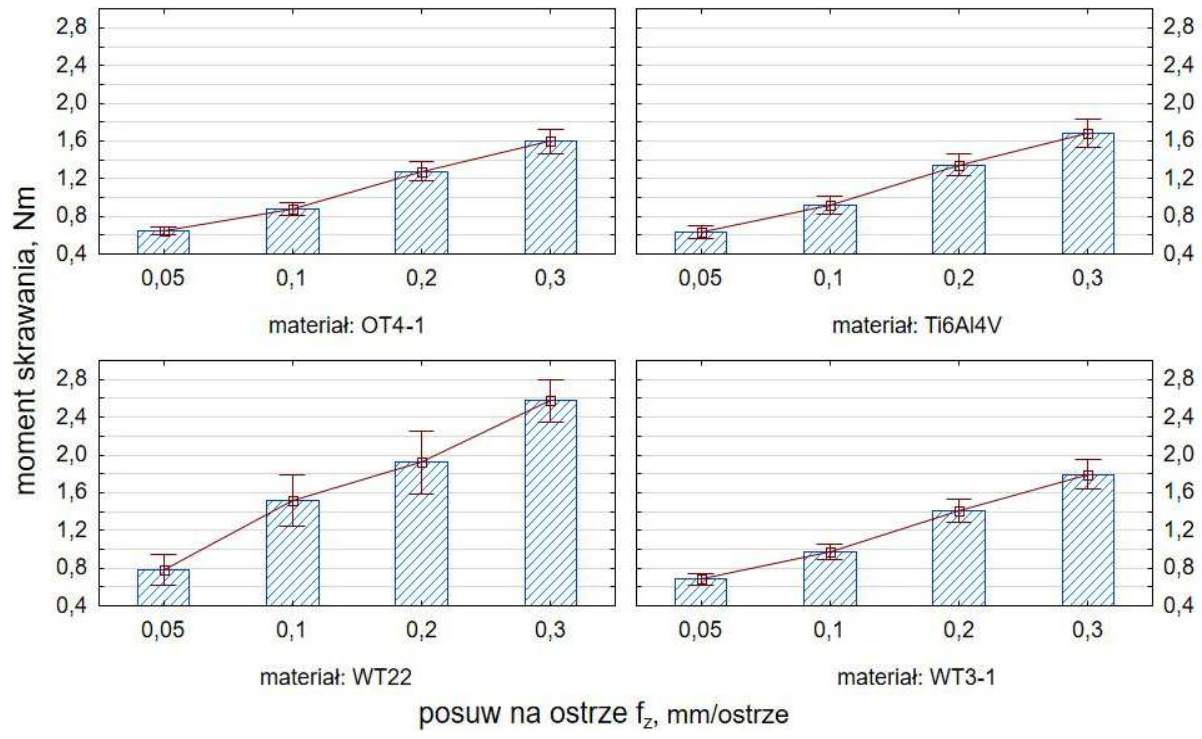

Rys. 5. Wpływ posuwu na ostrze $f_{z}$ na moment skrawania (stała prędkość $v_{c}=60 \mathrm{~m} / \mathrm{min}$ )

Fig. 5. The effect of feed per tooth $f_{z}$ on cutting torque (constant cutting speed $v_{c}=60 \mathrm{~m} / \mathrm{min}$ ) 


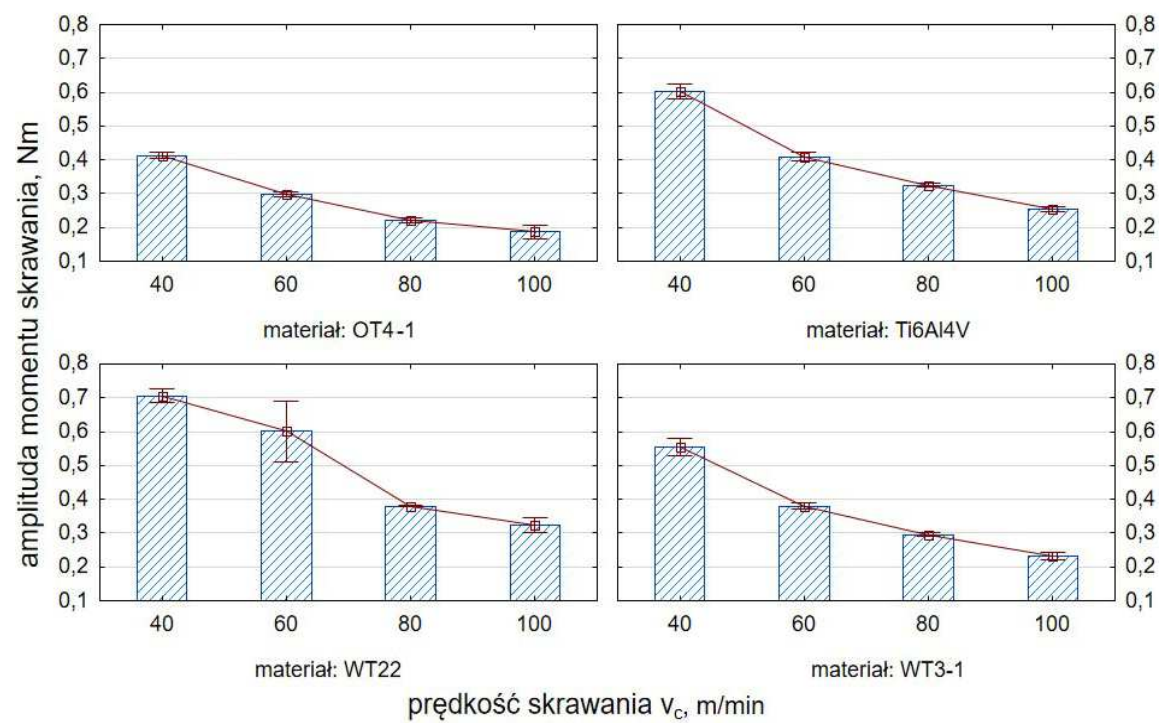

Rys. 6. Wpływ prędkości skrawania $v_{c}$ na amplitudę momentu skrawania (stały posuw $f_{z}=0,1 \mathrm{~mm} /$ ostrze)

Fig. 6. The effect of cutting speed $v_{c}$ on cutting torque amplitude (constant feed per tooth $f_{z}=0.1 \mathrm{~mm} /$ tooth)

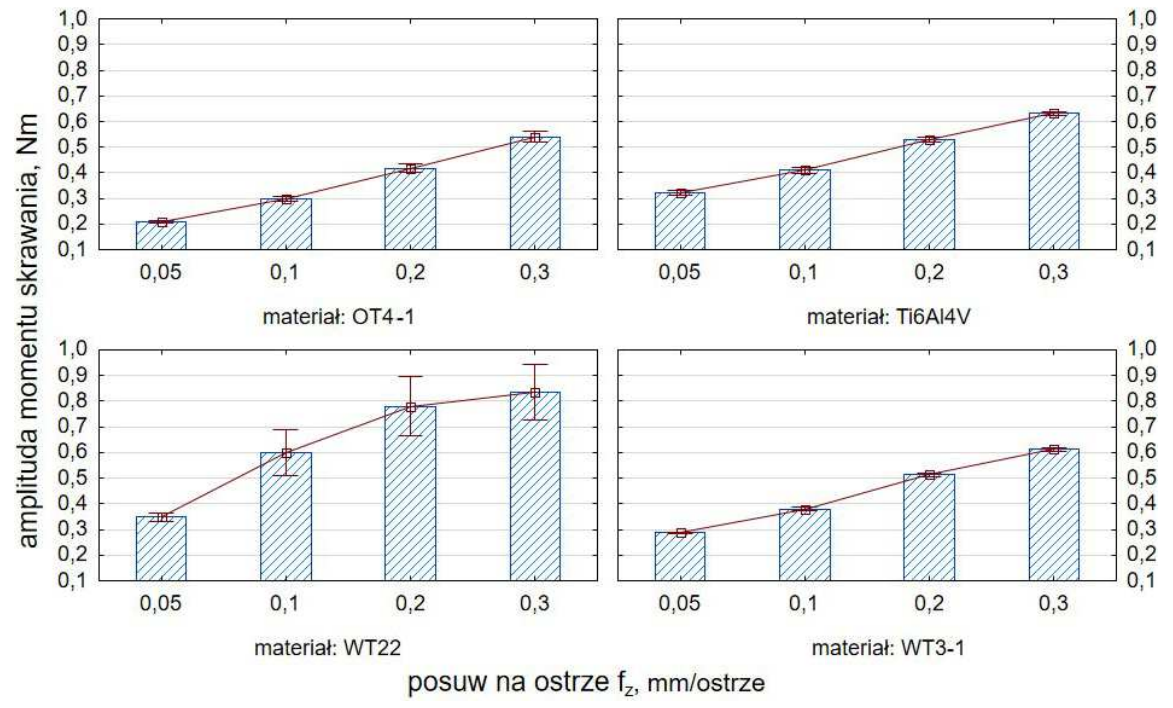

Rys. 7. Wpływ posuwu na ostrze $f_{z}$ na amplitudę momentu skrawania (stała prędkość $\left.v_{c}=60 \mathrm{~m} / \mathrm{min}\right)$

Fig. 7. The effect of feed per tooth $f_{z}$ on cutting torque amplitude (constant feed per tooth $f_{z}=0.1 \mathrm{~mm} /$ tooth) 
posuwu na ostrze na moment skrawania. Dla przyjętych w eksperymencie wartości posuwów moment zmieniał się $\mathrm{w}$ zakresie od 0,5 do $2,6 \mathrm{Nm}$. Na rysunkach 6 i 7 zobrazowano wpływ odpowiednio prędkości skrawania $v_{c}$ oraz posuwu na ostrze $f_{z}$ na amplitudę momentu skrawania. Można zaobserwować, że wraz ze wzrostem prędkości skrawania amplituda momentu maleje. Dla stopu WT22 charakteryzującego się największą wytrzymałością oraz twardością odnotowano wyraźnie większe wartości amplitudy momentu skrawania. Z kolei dla stopu OT4-1 wartości amplitudy momentu skrawania są najniższe w porównaniu z pozostałymi materiałami. Ze wzrostem posuwu można zauważyć wzrost amplitudy momentu skrawania.

\section{Podsumowanie}

W pracy przedstawiono wyniki badań porównawczych wpływu parametrów technologicznych skrawania na moment skrawania i chropowatość powierzchni podczas frezowania stopów tytanu Ti6Al4V, WT3-1, WT22 oraz OT4-1. Przeprowadzone badania eksperymentalne podsumowują następujące wnioski:

- istnieje zakres prędkości skrawania, dla których można otrzymać najmniejsze wartości parametrów chropowatości,

- podczas analizy wpływu prędkości skrawania na chropowatość powierzchni najwyższe wartości parametru $R a$ otrzymano po frezowaniu stopu tytanu WT22,

- prędkość skrawania w nieznacznym stopniu wpływała na średnią wartość momentu skrawania,

- zaobserwowano istotny wpływ prędkości skrawania i posuwu na ostrze na amplitudę momentu skrawania,

- wraz ze wzrostem prędkości skrawania amplituda momentu maleje,

- największe wartości momentu skrawania i jego amplitudy zaobserwowano podczas frezowania stopu tytanu WT22, co ma związek z właściwościami fizycznymi tego stopu,

- dla stopu OT4-1 zaobserwowano nieznacznie niższe wartości momentu skrawania i jego amplitudy w porównaniu z pozostałymi materiałami.

\section{Literatura}

[1] Burek J., Żurawski K., Żurek P.: Analiza składowych siły skrawania i naprężeń w warstwie wierzchniej metodą elementów skończonych w obróbce stopu tytanu Ti6Al4V, Mechanik, 88 (2015) 37-45.

[2] Honghua S.U., Peng L.I.U., Yucan F.U., Jiuhua X.U.: Tool life and surface integrity in high-speed milling of titanium alloy TA15 with PCD/PCBN tools, Chinese J. Aeronautics, 25 (2012) 784-790.

[3] Huang P.L., Li J.F., Sun J., Zhou J.: Study on performance in dry milling aeronautical titanium alloy thin-wall components with two types of tools, J. Cleaner Production, 67 (2014) 258-264. 
[4] Kołodziej M., Karolczak P.: Analiza wpływu warunków toczenia na chropowatość powierzchni i postać wiórów stopu tytanu Ti6Al4V, Mechanik, 89 (2016) 1486-1487.

[5] Krupa K., Laskowski P., Sieniawski J.: Wpływ zużycia ostrzy narzędzi i parametrów toczenia wykończeniowego na mikronierówności powierzchni elementów ze stopu Ti-6Al-2Sn-4Zr-6Mo, red. W. Grzesik: Obróbka skrawaniem. Nauka a przemysł, Szkoła Obróbki Skrawaniem, Wrocław/Opole 2011, ss. 417-424.

[6] Kuczmaszewski J., Zaleski K., Matuszak J., Pałka T., Garwacki R.: Wpływ średnicy frezu na jego zużycie podczas obróbki stopu tytanu Ti6Al4V, Mechanik, 90 (2017) 198-200.

[7] Lipski J., Litak G., Rusinek R., Szabelski K., Teter A., Warmiński J., Zaleski K.: Badania drgań w procesie toczenia stopu tytanu, red. M. Korzyński: Materiały VI Konf. N-T Wytwarzanie elementów maszyn ze stopów o specjalnych właściwościach, OW PRz, Rzeszów 2001, ss. 67-74.

[8] Nabhani F.: Machining of aerospace titanium alloys, Robotics Computer Integrated Manuf., 17 (2001) 99-106.

[9] Niesłony P., Habrat W.: Badania eksperymentalne oraz symulacje MES dla różnych modeli konstytutywnych procesu frezowania stopu Ti6Al4V, Mechanik, 87 (2014) 63-72.

[10] Polishetty A., Goldberg M., Littlefair G., Puttaraju M., Patil P., Kalra A.: A preliminary assessment of machinability of titanium alloy Ti6Al4V during thin wall machining using trochoidal milling, Procedia Eng., 97 (2014) 357-364.

[11] Słodki B., Zębala W., Struzikiewicz G.: Skuteczność doprowadzania cieczy obróbkowej pod ciśnieniem w procesie łamania wióra przy toczeniu wzdłużnym stopu Ti6Al4V, Mechanik, 88 (2015) 249-257.

[12] Stachurski W., Ostrowski D.: Wpływ głębokości skrawania podczas toczenia stopu Ti6Al4V ELI (Grade 23) na siły skrawania oraz chropowatość powierzchni obrobionej, Mechanik, 89 (2016) 1032-1033.

[13] Sun S., Brandt M., Dargush M.S.: Characteristics of cutting forces and chip formation in machining of titanium alloys, Int. J. Machine Tools Manuf., 49 (2009) 561-568.

[14] Zaleski K., Pałka T.: Badania chropowatości powierzchni po obróbce toczeniem stopu tytanu Ti6Al4V, ZN PRz, Mechanika, 66 (2006) 251-255.

[15] Zawora J., Marciniak M., Dąbrowski L.: Optymalizacja wielokryterialna procesu toczenia tytanu, Mechanik, 89 (2016) 1432-1433.

\section{COMPARATIVE STUDY OF THE INFLUENCE OF TECHNOLOGICAL PARAMETERS OF MILLING OF SELECTED TITANIUM ALLOYS ON CUTTING TORQUE AND SURFACE ROUGHNESS OF MACHINED SURFACE}

\section{S u m m a r y}

Titanium alloys are widely used in many industries. Because of the shape and dimensional accuracy requirements and surface quality, they are often subject to finishing machining. However, due to their properties they are difficult-to-cut materials. This paper presents the results of studies on the effect of cutting speed $v_{c}$ and feed per tooth $f_{z}$ on cutting torque, torque amplitude and surface 
roughness during milling of samples made of Ti6A14V, WT3-1, WT22 and OT4-1 titanium alloys. The research was carried out on a 3-axis machining centre. Kistler 9125A rotary dynamometer was used to measure the cutting torque. It was found that there is a range of cutting speeds $v_{c}$ for which the surface roughness is the smallest. It has been also shown that both the values and amplitudes of cutting torque are strongly correlated with the properties of the material.

Keywords: titanium alloys, cutting torque, torque amplitude, surface roughness

DOI: $10.7862 / \mathrm{rm} .2017 .53$

Przestano do redakcji: 14.08 .2017

Przyjęto do druku: 18.10 .2017 